\title{
Cell lysis of competitors and osmotrophy enhance growth of the bloom-forming alga Gonyostomum semen
}

\author{
Karin Rengefors* , Carina Pålsson, Lars-Anders Hansson, Lisa Heiberg \\ Department of Ecology/Limnology, Lund University, Ecology Building, 22362 Lund, Sweden
}

\begin{abstract}
The nuisance alga Gonyostomum semen (Raphidophyceae) is known to form dense blooms in many freshwater bodies, and has increased its distribution and abundance. However, information on the mechanisms behind bloom formation and maintenance is scarce. Field observations indicate that $G$. semen may be favored in humic lakes. In the present study, we performed controlled laboratory experiments on cultures to test whether G. semen growth is enhanced by humic acids. In addition, we tested the mixotrophic capability of $G$. semen by providing it with Rhodomonas lacustris as prey. G. semen increased its growth rate in the presence of humic substances due to either acquisition of carbon or some unknown growth factor. Moreover, growth rate was enhanced in the presence of $R$. lacustris, which in turn was negatively influenced when cultured together with G. semen. We found no evidence of phagotrophy, but observed lysis of $R$. lacustris cells exposed to G. semen pre-grown with $R$. lacustris. Thus, our experiments suggest that cell lysis (probably via trichocyst action) and osmotrophy could be 2 mechanisms involved in establishing and maintaining dominance of $G$. semen in humic lakes.
\end{abstract}

KEY WORDS: Cell lysis · Osmotrophy · Mixotrophy · Humic acids · Gonyostomum semen · Raphidophyceae $\cdot$ Nuisance bloom

\section{INTRODUCTION}

During the last 2 decades, the freshwater raphidophyte Gonyostomum semen Ehrenberg (hereafter referred to as Gonyostomum) has received increased scientific attention due to its propensity to form blooms and thereby negatively influence the recreational value of lakes. Originally, Gonyostomum was found mainly in small lakes and ponds with a high humic content (Eloranta \& Räike 1995, Pithart et al. 1997). During recent decades, however, there has been a trend toward a wider distribution in more nutrient-rich and non-humic environments (Cronberg 2005). In addition, there has been an increased frequency of blooms (Lepistö et al. 1994, Findlay et al. 2005) with cell concentrations up to $1.2 \times 10^{6} \mathrm{l}^{-1}$ (Hehmann et al. 2001). Although Gonyostomum has a worldwide distribution (Europe, Asia, North and South America,
Africa), blooms have been recorded primarily in the Fenno-Scandinavian countries (Eloranta \& Räike 1995). In the lakes of this region, Gonyostomum forms blooms that usually dominate the phytoplankton community completely, in particular during late summer (Salonen \& Rosenberg 2000). During such events, Gonyostomum often comprises up to $95 \%$ of the phytoplankton biomass (Cronberg et al. 1988, Hongve et al. 1988, Havens 1989, LeCohu et al. 1989, Pithart et al. 1997, Salonen et al. 2002, Willén 2003, Findlay et al. 2005). Its ability to form high density blooms (in combination with the discharge of mucilaginous strands when stimulated by physical contact) makes Gonyostomum a nuisance species that can cause skin irritation in swimmers and clog filters in water treatment plants (Cronberg et al. 1988, Hongve et al. 1988).

Several hypotheses have been proposed to explain the recent spreading of Gonyostomum and its ability to form 
blooms. There is a positive correlation between total phosphorus and Gonyostomum abundance (Hehmann et al. 2001, Findlay et al. 2005), and increasing eutrophication has been suggested as a possible cause (Hongve et al. 1988, Lepistö \& Saura 1998). However, the onset of blooms appears to be dependent on multiple factors. Gonyostomum occurs mostly in humic lakes with high concentrations of dissolved organic carbon (DOC), low $\mathrm{pH}$ and low light penetration. Hence, its ability to tolerate acidic conditions and low light levels may give it a competitive advantage over many other algae (Cronberg et al. 1988, Eloranta \& Räike 1995). Another important factor influencing bloom formation is the ability of Gonyostomum to form benthic resting cysts (Cronberg 2005, Figueroa \& Rengefors 2006). When environmental conditions become favorable, the resting cysts can act as a 'seed' bank for recruitment, and cyst germination may precede formation of high density swimming populations (Figueroa \& Rengefors 2006). Gonyostomum is also capable of detecting chemical cues released by grazers (Daphnia) and adjusts its recruitment rate from resting cysts in the sediment accordingly (Hansson 1996, 2000). As grazing by Daphnia species may be an important regulatory factor (Findlay et al. 2005), germination at low predator abundance might further increase the likelihood of Gonyostomum becoming dominant (Hansson 1996). Gonyostomum may also reduce grazing and metabolic losses by extensive vertical migrations (Salonen \& Rosenberg 2000). Furthermore, when migrating downward at night, Gonyostomum may access nutrients in the hypolimnion and thus overcome epilimnetic nutrient depletion (Salonen \& Rosenberg 2000). Vertical migration also allows the alga to adjust its position in the water column to that of optimal photosynthetic light conditions (Eloranta \& Räike 1995). However, information about Gonyostomum's growth mode is still rather limited and there have been few experimental studies with this alga.

The aim of the present study was to investigate whether Gonyostomum is mixotrophic, i.e. does it have the ability to combine phototrophy and heterotrophy, either by utilizing humic substances or by preying on bacteria and/or other algae. We propose that Gonyostomum's dominance in brownwater lakes is influenced by its ability to utilize humic substances and competing algae as nutrient sources. We tested this proposal by exploring the growth of Gonyostomum in controlled laboratory settings.

\section{MATERIALS AND METHODS}

Cultures. Two Gonyostomum semen (hereafter Gonyostomum) cultures (GSBO2 and GSTVB3) were established from single cell isolates from the humic lakes Bokesjön (September 2004) in southern Sweden and Tvigölen (September 2006) in central Sweden, respectively. Culture GSBO2 was used in Expts 1 to 3, while GSTVB3 was used for Expt 4 (since GSBO2 had died). Stock cultures were maintained in artificial freshwater MWC medium buffered at pH 7 (modified Woods Hole medium, Guillard \& Lorenzen 1972) at a photon flux of $30 \mu \mathrm{mol} \mathrm{m} \mathrm{m}^{-2} \mathrm{~s}^{-1}$. However, Gonyostomum was grown at a low light intensity $(10 \mu \mathrm{mol}$ $\mathrm{m}^{-2} \mathrm{~s}^{-1}$ ) in all experiments (in order not to inhibit potential mixotrophy by light over-saturation); this low photon flux approximates natural ambient light level. For example, in a Finnish humic lake Gonyostomum aggregated at $\leq 10 \mu \mathrm{mol} \mathrm{m} \mathrm{m}^{-2} \mathrm{~s}^{-1}$ (Eloranta \& Räike 1995). Maintenance cultures and experiments were kept in a temperature-controlled walk-in incubator at $20 \pm 1{ }^{\circ} \mathrm{C}$ under a light:dark cycle of $14: 10 \mathrm{~h}$.

Expt 1: Mixotrophy. In order to determine whether Gonyostomum grew better when provided with humic acids or with a prey, 3 treatments were set up: 'Control' with MWC medium only; 'Fulvic acids (FA)' with MWC medium and an addition of humic substances at $12 \mathrm{mg} \mathrm{l}^{-1}$ (equivalent to $5.2 \mathrm{mg} \mathrm{C} \mathrm{l}^{-1}$ ); and 'Rhodomonas' with MWC medium plus the addition of a potential algal prey (Rhodomonas lacustris, Cryptophyceae). Prior to the start of the experiment, Gonyostomum (GSBO2) was acclimated to the prevailing light regime for approximately 1 mo. The FA were obtained from Fredriks Research Products, and had been extracted from Laurential soils. The partial elemental composition of the FA (according to the supplier) was C $(42.3 \%), \mathrm{H}(4 \%), \mathrm{N}(0.83 \%), \mathrm{Na}$ $(0.27 \%)$, Fe $(0.013 \%)$, and ash $(<1 \%)$. Kritzberg et al. (2006) showed that this particular FA was utilized as a DOC source by a natural bacterial lake community. All treatments were replicated 6 times; however, 1 replicate of the FA treatment failed to grow after inoculation and the results presented from this treatment are based on 5 replicates.

At the start of the experiment, $109 \mathrm{ml}$ of medium was added to $250 \mathrm{ml}$ culture flasks (Nunclon ${ }^{\mathrm{TM}}$ ), which were inoculated to give an initial Gonyostomum concentration of 75 cells $\mathrm{ml}^{-1}$ (corresponding to a pre-bloom level). In the Rhodomonas treatment, Rhodomonas lacustris (NIVA 8/82) (hereafter Rhodomonas) cells were added at an initial density of 140 cells $\mathrm{ml}^{-1}$. Initial samples were immediately removed from the flasks, and subsequent samples were removed after $4,8,12,20,28,36$ and 40 d. Samples (total $9 \mathrm{ml}$ ) were split into 2 equal halves, one preserved with Lugol's acid solution and another with sterile-filtered glutaraldehyde $(2.5 \%$ final concentration). On each sampling occasion, the volume removed was replaced with fresh MWC medium. Thus, the volume in the culture bottles was kept 
constant at $100 \mathrm{ml}$. In the FA treatment, the replacement medium was enriched with FA.

Density counts of bacteria and Rhodomonas were obtained from the glutaraldehyde-preserved samples using a FACSort (Becton Dickinson) flowcytometer. Bacteria were stained with SYTO-13 according to del Giorgio et al. (1996), while Rhodomonas was identified from the fluorescence of chlorophyll and phycoerythrin. Gonyostomum was enumerated in settling chambers using an inverted microscope (Nikon Eclipse TS 100). Specific growth rates $\left(\mathrm{d}^{-1}\right)$ of Gonyostomum and Rhodomonas were determined by linear regressions of the natural log of cell densities against time, and were corrected for dilution effects.

On Day 40, samples were also collected for chlorophyll a (chl a) and mineral nutrient analysis. For chl a, a known volume from each replicate was filtered onto precombusted $\left(2 \mathrm{~h}, 450^{\circ} \mathrm{C}\right) \mathrm{GF} / \mathrm{F}$ filters (Whatman). The filters were stored frozen and chl a was extracted in ethanol overnight (Jespersen \& Christoffersen 1987). Chl a absorbance was measured on a Beckman DU 650 spectrophotometer. Gonyostomum cellular chl a concentrations for the Control and FA treatments were calculated by dividing total chl a by Gonyostomum density. Due to the presence of Rhodomonas cells in the Rhodomonas treatment, Gonyostomum cellular chl a could not be calculated. The cell-free filtrate was collected for nutrient analyses and stored frozen in acid-washed plastic vials. Concentrations of $\mathrm{PO}_{4}{ }^{3-}$ and $\mathrm{NO}_{3}{ }^{-}$were measured in randomly selected duplicates from each treatment using a Technicon Autoanalyzer II according to Technicon protocols and Swedish standard methods (SS028126 and SS028133; Bydén et al. 1996).

Expt 2: Growth by humic acid concentration. In this experiment, Gonyostomum was cultured in MWC medium with varying concentrations of humic substances. As before, maintenance cultivation and experiments were done in temperature-controlled walk-in incubators at $20 \pm 1^{\circ} \mathrm{C}$ under a light:dark cycle of $14: 10 \mathrm{~h}$ and a photon flux of $10 \mu \mathrm{mol} \mathrm{m} \mathrm{m}^{-2} \mathrm{~s}^{-1}$. Gonyostomum was grown with (1) $2 \mathrm{mg} \mathrm{FA} \mathrm{l}^{-1}\left(0.9 \mathrm{mg} \mathrm{C} \mathrm{l}^{-1}\right.$, Low treatment), (2) $9 \mathrm{mg} \mathrm{FA} \mathrm{l}^{-1}$ (3.9 $\mathrm{mg} \mathrm{C} \mathrm{l}^{-1}$, Medium treatment), and (3) $22 \mathrm{mg} \mathrm{FA} \mathrm{l}^{-1}$ (9.5 mg C l ${ }^{-1}$, High treatment). All treatments were run in 6 replicate flasks (Nunclon $^{\mathrm{TM}}$ ) with starting densities of approximately 90 Gonyostomum cells $\mathrm{ml}^{-1}$. Sampling was performed as described in Expt 1 except that samples were removed at $8 \mathrm{~d}$ intervals (apart from the last sampling, which was done after $76 \mathrm{~d}$ following a $4 \mathrm{~d}$ interval). Fresh medium was added on each sampling occasion. Densities of Gonyostomum were obtained by visual counts of Lugol's preserved samples (Nikon Eclipse TS 100) from alternate sampling dates. Again, growth rates were determined by linear regressions of the natural log of cell densities against time. Density counts of bacteria were obtained by flow cytometry of the glutaraldehyde-preserved samples from each sampling occasion as described above.

When the incubations were terminated on Day 76, samples were taken for chl $a$ and mineral nutrient analysis as described for Expt 1. Primary production rates were measured by the ${ }^{14} \mathrm{C}$ incorporation method (Wetzel \& Likens 1991) using one $23 \mathrm{ml}$ glass vial for each replicate and a control consisting of equal volumes of culture from the 6 replicates. $\mathrm{H}^{14} \mathrm{CO}_{3}$ (Amersham CFA3, specific activity $58 \mathrm{mCi}$ (2.15 GBq) $\left.\mathrm{mmol}^{-1}\right)$ was added $(1.76 \mu \mathrm{Ci}$ final activity) and the vials were incubated for approximately $4 \mathrm{~h}$. During incubation, all vials except the control (incubated in darkness) were exposed to the same light and temperature conditions as the original cultures. Cell-specific primary production rates were calculated for each treatment by dividing the production rate $\mathrm{h}^{-1}$ by cell density. Cell-specific primary production rates normalized to chl a were calculated by dividing the production rates by cellular concentrations of chl a.

Bacterial abundance and production were measured to determine whether they were correlates of Gonyostomum growth rate and/or density. Bacterial production (Day 76 only) was measured by the incorporation of leucine (Amersham TRK 510, specific activity $22.5 \mathrm{Ci} \mathrm{mmol}{ }^{-1}$, final concentration $100 \mathrm{nmol} \mathrm{l}^{-1}$ ) according to Smith \& Azam (1992). The incubations (approximately $60 \mathrm{~min}$ ) were performed with samples $(1.7 \mathrm{ml})$ from each replicate plus one trichloroacetic acid (TCA)-killed control. The incubations were terminated by the addition of TCA ( $5 \%$ final concentration) and bacteria were concentrated to pellets by centrifugation at $15000 \times g$ for $10 \mathrm{~min}$. The pellets were rinsed with $5 \%$ TCA and $80 \%$ ethanol. Finally, $0.5 \mathrm{ml}$ of scintillation cocktail (Ecoscint A, Kimberly Research) were added to each and ${ }^{3} \mathrm{H}$ activity was measured on a Beckman LS 6500 Scintillation counter. Leucine incorporation rates were transformed into bacterial carbon production rates according to Smith \& Azam (1992). All statistical analyses were performed using SPSS 10 software. Data was tested for variance homogeneity and normality prior to running ANOVAs.

Expt 3: Rhodomonas disappearance. In order to determine whether Gonyostomum preyed upon Rhodomonas, a prey disappearance experiment was conducted after terminating Expt 1. The design included a treatment with Rhodomonas exposed to Gonyostomum cells, while the control consisted of Rhodomonas with cell-free Gonyostomum culture medium. The cell-free Gonyostomum medium was used (instead of MWC medium only) to rule out any differences resulting from potential water-released allelochemicals. The mixed cultures from Expt 1 were thus used in order to 
include Gonyostomum that was acclimated to prey. For the Gonyostomum treatment, $25 \mathrm{ml}$ were transferred to each of 3 culture flasks (Nunclon ${ }^{\mathrm{TM}}$ ). The Gonyostomum:Rhodomonas abundance ratio in this treatment was set to approximately $1: 24$ by adding more Rhodomonas cells. For the Control treatment, the remaining volume of mixed culture was gravity filtered consecutively through 25 and $10 \mu \mathrm{m}$ nets in order to remove Gonyostomum. Due to its trichocysts, Gonyostomum clogs filters rapidly, and sequential filtration is needed to remove all cells. The filtrate was transferred to 3 replicate flasks with a final volume of $25 \mathrm{ml}$ each. The removal of Gonyostomum from the Control was successful and no Gonyostomum cells were found in this treatment. In the treatment with Gonyostomum, densities were $536 \pm 96$ cells ml$^{-1}$ (mean \pm SD). Filtration also removed some Rhodomonas and starting densities were $13.1 \pm 0.94 \times 10^{3}$ and $10.7 \pm 0.70 \times 10^{3}$ cells $\mathrm{ml}^{-1}$ in the Gonyostomum and Control treatments, respectively. Samples (5 ml preserved with Lugol's acid solution and sterile filtered glutaraldehyde, $2.5 \%$ final concentration) were removed immediately to estimate starting densities of Gonyostomum and Rhodomonas. Additional samples $(5 \mathrm{ml})$ were removed after 8 and 29 h. In between sample retrievals, the culture bottles were exposed to the same light and temperature conditions as those in Expt 1.

Densities of Rhodomonas were counted by flow cytometry as described above, and Rhodomonas specific growth rates $\left(\mathrm{d}^{-1}\right)$ were determined by linear regressions of the natural log of cell densities against time. Disappearance rates were determined from the reduction in Rhodomonas densities in the treatment with Gonyostomum compared to the Control, assuming exponential growth (following Skovgaard 1996):

$$
\frac{\mathrm{d} X}{\mathrm{~d} t}=\mu_{X} X-U Y
$$

and

$$
\frac{\mathrm{d} Y}{\mathrm{~d} t}=\mu_{Y} Y
$$

where $X$ is prey concentration, $Y$ is Gonyostomum concentration, $\mu$ is specific growth rate, $U$ is per capita ingestion rate, and $U Y$ is the mortality of prey.

In order to further investigate the potential phagotrophy of Gonyostomum on Rhodomonas, we examined Gonyostomum for food vacuoles in a parallel experiment. The remaining 3 replicates from treatment P were mixed and Rhodomonas was added to a 1:24 Gonyostomum:Rhodomonas ratio, as described above. Sub-samples were removed from each of 3 replicates and live samples were observed continually in Sedgewick-Rafter chambers under light microscopy over the first few hours, and then hourly for up to $8 \mathrm{~h}$. In addition, samples $(8 \mathrm{ml})$ from each replicate were collected at the start and after $8 \mathrm{~h}$ incubation at $20^{\circ} \mathrm{C}$ and $10 \mu \mathrm{mol}$ photons $\mathrm{m}^{-2} \mathrm{~s}^{-1}$. The samples were preserved with ice-cold glutaraldehyde $(2.5 \%$ final concentration) and were filtered onto $25 \mathrm{~mm}$ black $5 \mu \mathrm{m}$ pore size polycarbonate membrane filters (Osmonics). Cells were stained with DAPI or CYTOX according to Sherr \& Sherr (1993) and Gonyostomum was examined for food vacuoles using epifluorescence microscopy (Nikon Labophot-2) at 1000× magnification.

Expt 4: Lysis experiment. A follow-up experiment to Expt 3 was performed in order to test whether lysis (due to cell contact or an exuded chemical) was the mechanism that led to the disappearance of Rhodomonas. To do this, we ran a $72 \mathrm{~h}$ experiment with Rhodomonas cells exposed to live Gonyostomum cells or cell-free filtrates. By testing cell-free filtrates, any effect due to chemical mediated lysis (allelopathy) could be separated from cell-contact mediated lysis. Rhodomonas cells were exposed to 4 different treatments: MWC medium only (Control); Gonyostomum cells grown in unialgal culture (Single); 'induced' Gonyostomum pre-grown in a mixed culture with Rhodomonas for $9 \mathrm{~d}$ (Induced); and Gonyostomum-free filtrate from Gonyostomum pre-grown with Rhodomonas (Filtrate). As the GSBO2 culture had died, GSTVB3 was used. Treatments were set up in 24-well Nunc plates (Nunclon), with 4 replicate wells per treatment, in 5 parallel sets for 5 sampling occasions. The initial Rhodomonas cell concentration was $8860 \mathrm{ml}^{-1}$ in all treatments. The cell concentration of Gonyostomum was $370 \mathrm{ml}^{-1}$ in the Single treatment, thereby reaching the 1:24 Rhodomonas:Gonyostomum cell ratio used in the prey disappearance experiment. For the Control treatment, Rhodomonas was added from a culture of Rhodomonas grown unialgally to a reach a final concentration of $8860 \mathrm{ml}^{-1}$. For the Induced treatment, most Rhodomonas cells were removed by filtering through a $10 \mu \mathrm{m}$ Nytex net, and the Gonyostomum cells were resuspended with fresh medium. Unialgal Rhodomonas cultures were added to reach a final concentration of $8860 \mathrm{ml}^{-1}$. The filtrate from the mixed Gonyostomum and Rhodomonas culture was utilized for the Filtrate treatment. The $10 \mu \mathrm{m}$ filtrate was passed through a $2.0 \mu \mathrm{m}$ filter to remove remaining Rhodomonas cells. This filtrate nevertheless contained 9847 Rhodomonas cells ml ${ }^{-1}$ and was used for the filtrate treatment. Since each well contained $1 \mathrm{ml}$ filtrate and $950 \mu \mathrm{l}$ of MWC medium, additional Rhodomonas cells were added to reach a final concentration of $8860 \mathrm{ml}^{-1}$ in the wells. A smaller pore filter was not used, as these become clogged with Gonyostomum trichocysts. To minimize any affect of nutrient limitations, at least $0.5 \mathrm{ml}$ of replete MWC medium was added to all treatments. The total volume was $2 \mathrm{ml}$ in all wells.

The plates were incubated at $20^{\circ} \mathrm{C}, 10 \mu \mathrm{mol}$ photons $\mathrm{m}^{2} \mathrm{~s}^{-1}$ on a 14:10 light:dark cycle. A set of samples was 
harvested after $4,8,24,48$ and $72 \mathrm{~h}$ by adding $15 \mu \mathrm{l}$ of Lugol's solution. Samples were counted at $40 \times$ magnification directly in the wells.

\section{RESULTS}

\section{Expt 1: Mixotrophy}

The highest densities of Gonyostomum were obtained in the Rhodomonas treatment followed by the FA and Control (pure MWC) treatments (Fig. 1) (repeated measures ANOVA: $F=12.75, \mathrm{df}=2, \mathrm{p}<0.001)$. The mean Gonyostomum specific growth rate (0.158 \pm $0.010 \mathrm{~d}^{-1}$ based on $40 \mathrm{~d}$ of incubation, mean \pm SD) obtained in the Rhodomonas treatment was significantly higher than in the FA treatment, which was followed by the Control $(0.140 \pm 0.004$ and $0.125 \pm 0.008$ $\mathrm{d}^{-1}$, respectively; ANOVA: $F=24.42, \mathrm{df}=2$, Tukey's HSD, p < 0.001) (Table 1). Moreover, bacterial densities were highest in the Rhodomonas treatment throughout the experiment $\left(19.8 \times 10^{6} \pm 5 \times 10^{6}\right.$ bacteria $\mathrm{ml}^{-1}$ on Day 40; Table 1, repeated measures ANOVA: $F=50.64, \mathrm{df}=2, \mathrm{p}<0.001$ ) compared to the FA and the Control treatments. There were no significant differences in Gonyostomum cell-specific concentrations of chl a among the Control and FA treatments ( $t$-test, $\mathrm{p}>0.05$, Table 1$)$. Concentrations of nitrate and phosphate on Day 40 were similar in the 3 treatments and ranged between 11.9-13.6 $\mathrm{mg} \mathrm{NO}_{3}^{-} \mathrm{l}^{-1}$ and $1.5-1.9 \mathrm{mg} \mathrm{PO}_{4}{ }^{3-} \mathrm{l}^{-1}$.

In the Rhodomonas treatment, mean Rhodomonas cell density was $11.7 \times 10^{3} \mathrm{ml}^{-1}$ on Day 40 , with a large variation between the replicates $(\mathrm{SD}=2.7 \times$ $10^{3}$ cells $\mathrm{ml}^{-1}$ ). A major part of this variation can be explained by the abundance of Gonyostomum because densities of Rhodomonas were negatively correlated with densities of Gonyostomum during the last 2 wk of incubation (when the treatments had entered a faster growth phase and started diverging, see Fig. 1, linear regression, $p<0.01, r^{2}=0.336$; Fig. 2). When the entire growth period was included in the regression, no significant negative correlation was found.
0.001) (Fig. 3). When Gonyostomum average growth rates were determined for the entire incubation period (76 d), they differed considerably among treatments (ANOVA, p < 0.001); the highest rate was obtained in the Low treatment $\left(0.2074 \pm 0.0010 \mathrm{~d}^{-1}\right)$ followed by the Medium $\left(0.2034 \pm 0.0022 \mathrm{~d}^{-1}\right)$ and High $(0.1965 \pm$

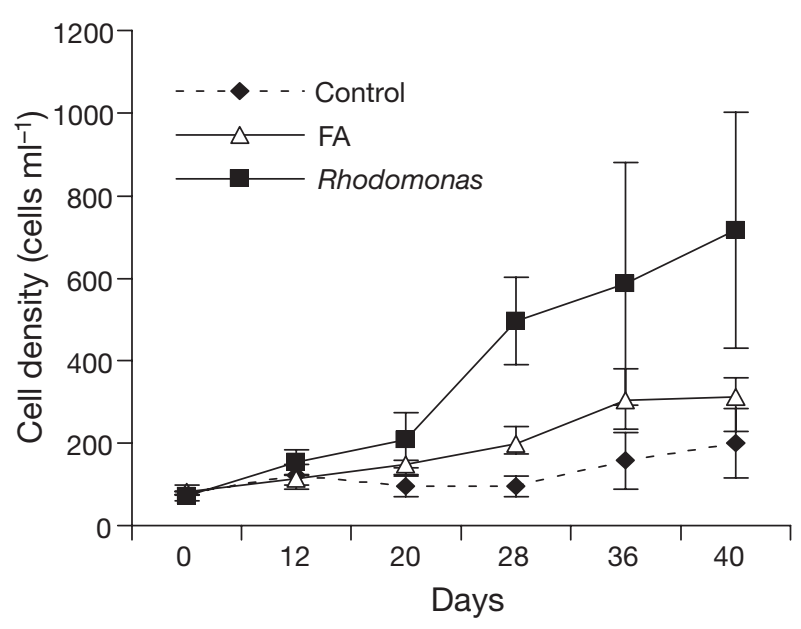

Fig. 1. Gonyostomum semen. Expt 1: Cell densities (means \pm $\mathrm{SD})$ after $40 \mathrm{~d}$ at low light intensity $\left(10 \mu \mathrm{mol}\right.$ photons $\left.\mathrm{m}^{-2} \mathrm{~s}^{-1}\right)$ in pure MWC medium (Control, $\mathrm{n}=6$ ), MWC enriched with fulvic acids (FA) (12 $\left.\mathrm{mg} \mathrm{l}^{-1} ; \mathrm{n}=5\right)$, and MWC with Rhodomonas lacustris (Rhodomonas, $\mathrm{n}=6$ )

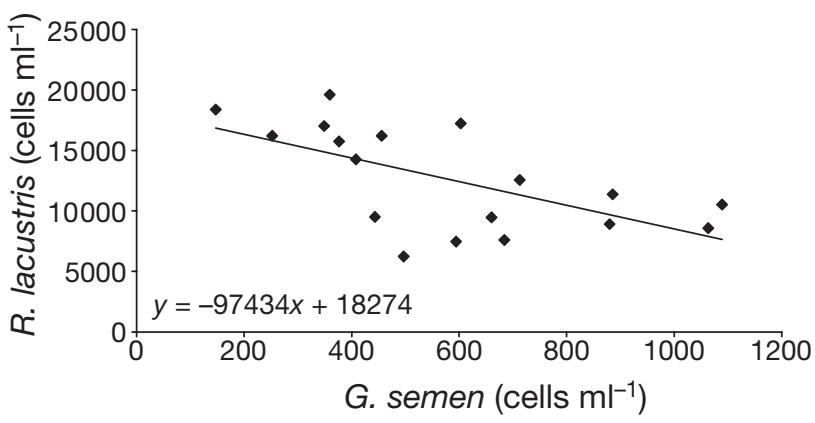

Fig. 2. Gonyostomum semen and Rhodomonas lacustris. Expt 1: Relationship between cell densities (cells ml-1) in mixed cultures during the last $12 \mathrm{~d}$ of incubation (linear regression, $\mathrm{p}<0.01$, adj. $\left.\mathrm{r}^{2}=0.336\right)$

\section{Expt 2: Growth by humic acid concentration}

In the growth by humic acid concentration experiment, the highest densities of Gonyostomum were reached in the treatment with the lowest FA concentration, followed by the Medium and High treatments (repeated measures ANOVA: $F=88.73, \mathrm{df}=2, \mathrm{p}<$
Table 1. Gonyostomum semen. Expt 1: Mean (SD) growth rate, bacterial abundances (BA) and Gonyostomum cellular chl a concentrations on Day 40 in cultures at low light intensity $\left(10 \mu \mathrm{mol}\right.$ photons $\left.\mathrm{m}^{-2} \mathrm{~s}^{-1}\right)$ and grown in (1) pure MWC medium (Control), (2) MWC enriched with fulvic acids (FA), and (3) mixed culture with Rhodomonas lacustris (Rhodomonas). $\mathrm{n}=6$ (for treatment FA, $\mathrm{n}=5$ ); -: not measured/applicable

\begin{tabular}{|lccc|}
\hline Treatment/parameter & Control & FA & Rhodomonas \\
\hline Specific growth rate $\left(\mathrm{d}^{-1}\right)$ & $0.12(0.008)$ & $0.14(0.003)$ & $0.16(0.01)$ \\
BA $\left(\times 10^{6}\right.$ cells ml $\left.^{-1}\right)$ & $7.0(0.7)$ & $9.2(0.7)$ & $19.8(5.0)$ \\
Chl $a\left(\mathrm{pg} \mathrm{cell}^{-1}\right)$ & $258(27)$ & $296(31)$ & - \\
\hline
\end{tabular}




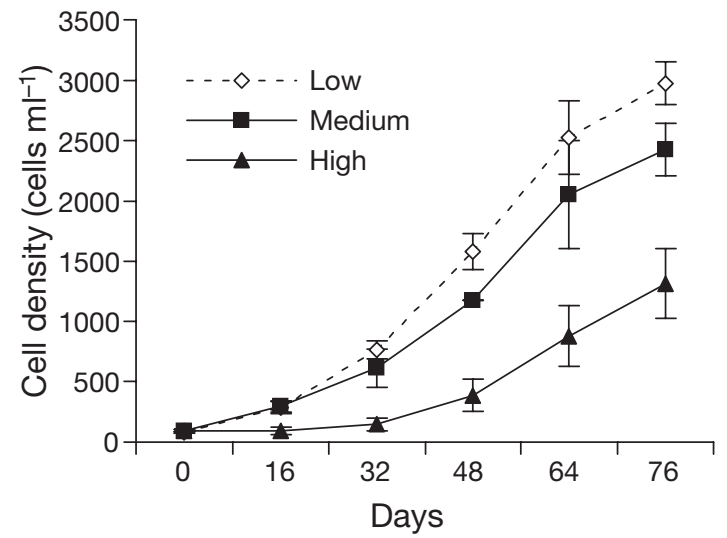

Fig. 3. Gonyostomum semen. Expt 2: Cell densities at a low light intensity $\left(10 \mu \mathrm{mol}\right.$ photons $\left.\mathrm{m}^{-2} \mathrm{~s}^{-1}\right)$ in MWC medium enriched with fulvic acids at $2 \mathrm{mg}^{-1}$ (Low), $9 \mathrm{mg} \mathrm{l}^{-1}$ (Medium) and $22 \mathrm{mg} \mathrm{l}^{-1}$ (High). Means $\pm \mathrm{SD}, \mathrm{n}=6$

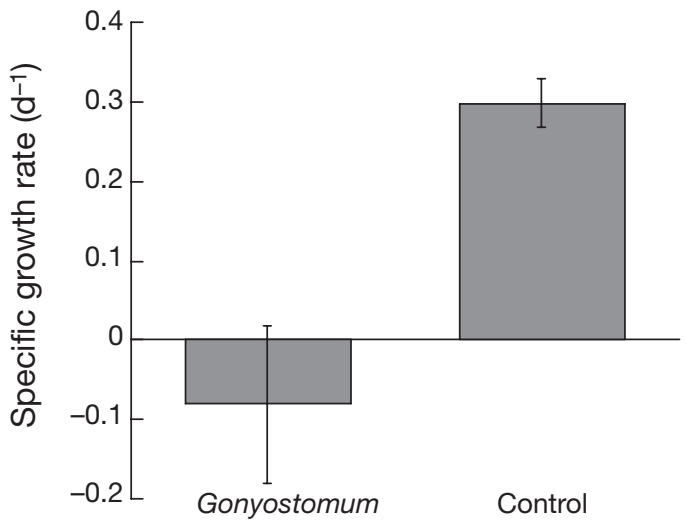

Treatment

Fig. 4. Rhodomonas lacustris. Expt 3: Specific growth rates in cultures with Gonyostomum semen (Gonyostomum) or from which Gonyostomum had been removed (Control). Means $\pm \mathrm{SD}, \mathrm{n}=3$

Table 2. Expt 3: Mean (SD) bacterial abundances (BA), bacterial production (BP), cellular concentrations of chl a in Gonyostomum, cellular production rates (PP) and production rates normalized to chl a on Day 76 in Gonyostomum cultures grown in MWC medium enriched with fulvic acids at $2 \mathrm{mg} \mathrm{l}^{-1}$ (Low), $9 \mathrm{mg} \mathrm{l}^{-1}$ (Medium) and $22 \mathrm{mg} \mathrm{l}^{-1}$ (High) at a low light intensity (10 $\mu \mathrm{mol}$ photons $\left.\mathrm{m}^{-2} \mathrm{~s}^{-1}\right) \cdot \mathrm{n}=6$

\begin{tabular}{|lccc|}
\hline Treatment/Parameter & Low & Medium & High \\
\hline $\mathrm{BA}\left(\times 10^{6} \mathrm{cells} \mathrm{m}^{-1}\right)$ & $19.9(3.5)$ & $18.6(3.7)$ & $16.7(4.0)$ \\
$\mathrm{BP}\left(\mu \mathrm{C} \mathrm{l}^{-1} \mathrm{~h}^{-1}\right)$ & $10.6(0.8)$ & $8.7(0.7)$ & $10.1(2.3)$ \\
$\mathrm{Chl}\left(\mathrm{pg} \mathrm{cell}^{-1}\right)$ & $376(26)$ & $360(33)$ & $333(29)$ \\
$\mathrm{PP}\left(\mathrm{pg} \mathrm{Cell}^{-1}\right)$ & $39.7(4.4)$ & $43.6(5.9)$ & $75.5(5.8)$ \\
PP chl a ${ }^{-1}\left(\mathrm{pg} \mathrm{C} \mathrm{pg} \mathrm{chl} \mathrm{a}{ }^{-1}\right)$ & $0.11(0.01)$ & $0.12(0.02)$ & $0.23(0.03)$ \\
\hline
\end{tabular}

$0.0035 \mathrm{~d}^{-1}$ ) treatments. By Day 76, growth rates had leveled out in the Low and Medium treatments, but not in the High treatment. Bacterial densities continued to increase throughout the experiment, reaching approximately $20 \times 10^{6}$ cells $\mathrm{ml}^{-1}$ on Day 76 (Table 2 ). No differences in bacterial abundance (BA) and production rate $(\mathrm{BP})$ were observed among the treatments on Day 76 (ANOVA: $F \mathrm{BA}=1.1, F \mathrm{BP}=2.66, \mathrm{df}=2, \mathrm{p}>0.050$ ) (Table 2).

Gonyostomum cell-specific concentrations of chl a ranged between 333 and $376 \mathrm{pg} \mathrm{chl} \mathrm{a} \mathrm{cell}{ }^{-1}$ and were not affected by the differing additions of FA (Table 2, ANOVA: $F=3.34, \mathrm{df}=2, \mathrm{p}>0.050)$. A higher rate of cell-specific primary production was measured on Day 76 in the High treatment $\left(75.5\right.$ pg C cell ${ }^{-1} \mathrm{~h}^{-1}$ ) than in the Low and Medium treatments (39.7 and 43.6 pg C cell ${ }^{-1} \mathrm{~h}^{-1}$, respectively; ANOVA: $F=79.68$, $\mathrm{df}=2, \mathrm{p}<0.001)$. In addition, primary production per unit of chl a varied significantly among treatments (ANOVA: $F=63.34$, df $=2, \mathrm{p}<0.001$ ), and production in the High treatment was double that in the other 2 treatments (Table 2). The concentrations of nitrate and phosphate were similar in all treatments and ranged from 12.0 to 13.0 and 2.9 to $3.7 \mathrm{mg} \mathrm{l}^{-1}$, respectively.

\section{Expt 3: Rhodomonas disappearance}

In the disappearance experiment, Rhodomonas growth rates were significantly lower in the Gonyostomum treatment $\left(-0.081 \pm 0.099 \mathrm{~d}^{-1}\right)$ than in the Control $\left(0.298 \pm 0.031 \mathrm{~d}^{-1}, t\right.$-test, $\mathrm{p}<0.01$, Fig. 4). This difference was equivalent to a disappearance rate of approximately 0.7 Rhodomonas cells per Gonyostomum cell $\mathrm{h}^{-1}$, or 20 Rhodomonas cells per Gonyostomum cell over the course of the experiment.

No food vacuoles were observed in Gonyostomum cells in either stained (DAPI and CYTOX) or live cells (epifluorescent microscopy). More than 400 cells were checked. The abundant trichocysts and their tendency to discharge during handling made it difficult to determine whether or not Rhodomonas cells observed in filter samples were truly ingested. However, in live samples it was clear that Gonyostomum did not contain food vacuoles. Moreover, when examining live samples, no behavior indicating phagotrophic ingestion was apparent. The observations, however, revealed that close contact between the 2 species often resulted in lysis of Rhodomonas, which led to execution of Expt 4. 


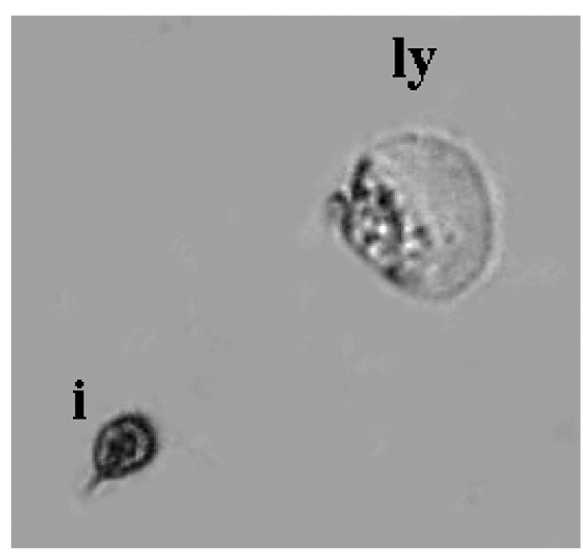

Fig. 5. Rhodomonas lacustris (length $=10 \mu \mathrm{m}$ ). Expt 4: Light micrograph of intact (i) and lysing (pre-lysed) (ly) cells in the treatment that included a Gonyostomum culture pre-grown with Rhodomonas cells. Cultures were not axenic

\section{Expt 4: Lysis experiment}

Rhodomonas exposed to induced Gonyostomum cells, i.e. Gonyostomum cells that had been pre-grown with Rhodomonas for $9 \mathrm{~d}$ (Induced treatment), were deformed and swollen, and appeared to be lysing (Fig. 5). These 'pre-lysed' cells were first observed after $4 \mathrm{~h}$ and increased to $12 \%$ of the total cell number after $72 \mathrm{~h}$ (Fig. 6A). The number of pre-lysed cells in the Induced treatment was significantly higher than the other treatments (repeated measures ANOVA: $F=$ 25.39, df $=3$, Bonferroni pairwise comparison, $\mathrm{p}<$ 0.001). In the Filtrate treatment, some pre-lysed cells appeared after $72 \mathrm{~h}$ and amounted to $3 \%$. However, there was no decline in intact cells among the 4 treatments during this time period (Fig. 6B). In the Filtrate treatment, Rhodomonas cell number was slightly and significantly higher (repeated measures ANOVA: $F=25.39, \mathrm{df}=3$, Bonferroni pairwise comparison, $\mathrm{p}<0.001)$

\section{DISCUSSION}

The occurrence of Gonyostomum blooms has increased in Fenno-Scandian freshwaters during recent decades, and several specific features have been suggested as explanations for its success (e.g. Lepistö et al. 1994, Salonen \& Rosenberg 2000). We performed controlled laboratory experiments to examine some nutritional strategies of Gonyostomum that may influence bloom formation and maintenance. Growth of Gonyostomum was stimulated by the presence of FA, which may explain its preference for humic lakes. In addition, we found that Gonyostomum enhanced its own growth when cultured with another alga (Rhodomonas that was eliminated by cell lysis). We propose that these are mechanisms by which Gonyostomum attains high biomass, and achieves and maintains dominance.

In our experiments, growth of Gonyostomum was positively influenced both by the presence of a small alga and by the addition of humic substances (FA). The experiments were conducted under controlled environmental conditions with fixed temperature and low light, using a culture medium with high nutrient concentrations and a neutral $\mathrm{pH}$. We suggest that the observed growth enhancement resulted from heterotrophic nutrition, specifically osmotrophy. In the mixotrophy experiment (Expt 1), the highest growth rates of Gonyostomum were obtained when it was cultured together with the cryptophyte Rhodomonas lacustris, which is a common lake phytoplankter. In contrast, growth of Rhodomonas appeared to be inhibited by the presence of Gonyostomum, as indicated by the negative relationship between densities of the 2 species and the results from the disappearance experi-
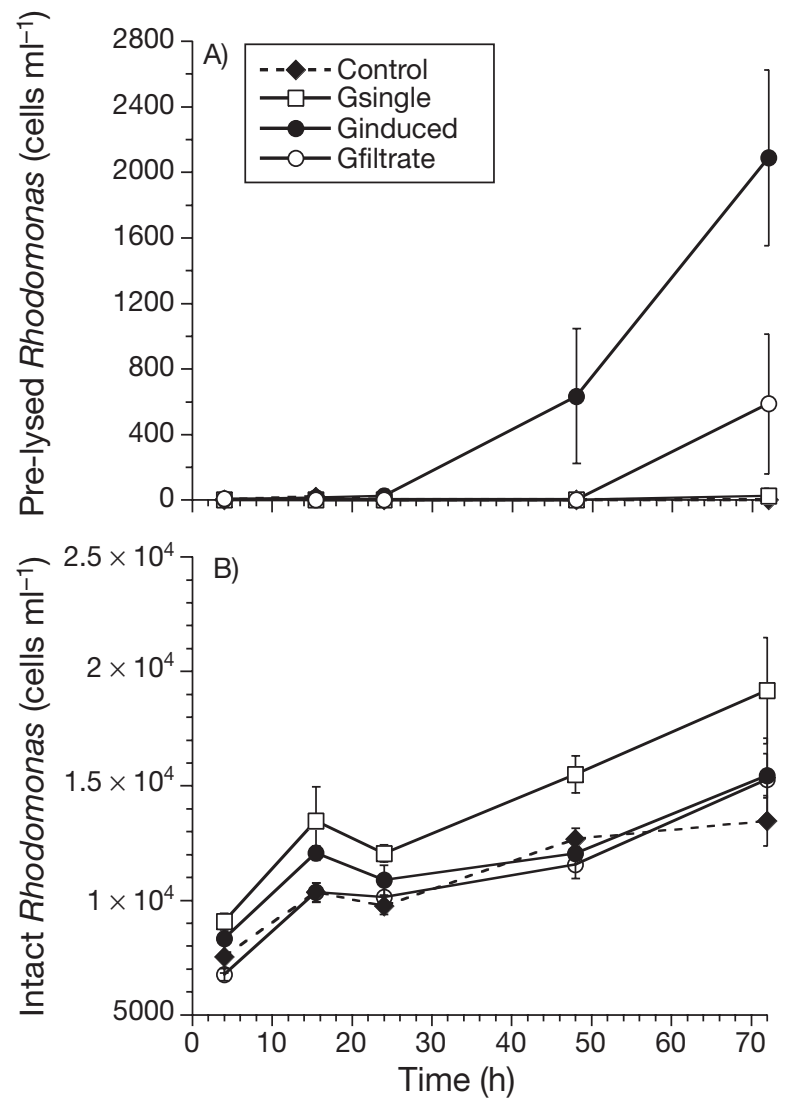

Fig. 6. Rhodomonas lacustris. Expt 4. (A) Abundance of prelysed cells. (B) Abundance of intact cells. Means \pm SD $(n=4)$ are shown. Gsingle: Gonyostomum grown in uni-algal culture; Ginduced: Gonyostomum pregrown with Rhodomonas; Gfiltrate: filtrate from induced treatment; Control: MWC medium only 
ment (Expt 3). The disappearance and lysis experiments (Expts 3 and 4) indicated that the suppression of Rhodomonas was due to cell lysis and not phagotrophy. Because of the high concentrations of nutrients in the culture medium, it is unlikely that Gonyostomum was favored by release of nutrients following lysis of its competitor. Rather, the higher growth rates were likely the result of a heterotrophic uptake of carbon (mixotrophy).

Mixotrophic nutrition (phagotrophy or osmotrophy) may be a means by which phytoplankton obtain carbon to supplement or even substitute the photosynthetic supply when light availability is too low to meet the metabolic demands of the cell (Jones 2000). Gonyostomum is often found in low light environments (Eloranta \& Räike 1995, Pithart et al. 1997, Findlay et al. 2005) and has also been reported to remain in the dark hypolimnion during daytime (Salonen \& Rosenberg 2000). In field studies, high abundances of Gonyostomum have correlated with increased DOC concentrations (humic substances) (Pithart et al. 1997, Lepistö \& Saura 1998, Hehmann et al. 2001, Findlay et al. 2005). This response has been explained primarily by Gonyostomum's ability to tolerate acidification and reduced light climate in brown-water humic lakes. However, the results from Expt 1 suggest carbon assimilation by mixotrophic nutrition as an explanation for the correlation between Gonyostomum and DOC/ water color. Growth rates were significantly higher than controls in the Rhodomonas treatment and in the treatment with added FA, while light climate, culture medium, and $\mathrm{pH}$ were constant. An alternative hypothesis is that the humic substances and lysed Rhodomonas cells contain some growth factor or trace element(s) not found in the MWC medium (which contains trace metals and vitamins).

Other phytoplankton species are also known to be stimulated by high DOC availability. For instance, growth of the green alga Chlamydomonas sp. is enhanced by high DOC availability even when photosynthesis is saturated and inorganic nutrients are available (Tittel \& Kamjunke 2004). In Chlamydomonas, the high DOC assimilation relative to total algal production $(23 \%)$ indicates the considerable importance of heterotrophic carbon uptake, which is probably even higher at lower light intensities (Tittel \& Kamjunke 2004). Likewise, Ochromonas growth is enhanced by the organic MES buffer in its medium (Sanders et al. 2001). The marine dinoflagellate Alexandrium catenella can take up high molecular weight dextrans (carbohydrate macromolecules), which provides evidence that large molecules such as humic substances can be taken up by mixotrophic algae (Legrand \& Carlsson 1998).
In the humic acid growth experiment (Expt 2), we compared the effects of different FA concentrations on Gonyostomum growth. The highest mean densities and growth rates were obtained in the treatment with the lowest concentration of humic acids (2 $\mathrm{mg} \mathrm{FA} \mathrm{l}^{-1}$ ) and growth could not be further enhanced by increased FA concentration. It should be noted that the FA level used in the initial mixotrophy experiment was $12 \mathrm{mg} \mathrm{FA}^{-1}$, i.e. in the range of the Medium and High treatments. Cell densities and growth rates for all treatments reached higher levels than in the initial mixotrophy experiment. This finding can be explained by the less frequent sampling, and thereby diminished disturbance of Gonyostomum cells. Gonyostomum cells are fragile and easily explode during handling. There was no indication that there were differences in the light climate among the different treatments (due to different concentrations of humic acids), as indicated by the similar cellular chl a content in all treatments. By the end of the experiment, growth rate appeared to level off and proceed into stationary phase in the Low and Medium treatments, in which cell concentrations had reached approximately $3000 \mathrm{ml}^{-1}$. Typically, our cultures reached between 3500 and 4000 cells ml ${ }^{-1}$ before collapsing (K. Rengefors unpubl. data). No leveling off was noted in the High treatment, where cell densities had reached only $1200 \mathrm{ml}^{-1}$ by the termination of the experiment. These findings were corroborated by the high primary production in the High treatment on Day 76, which was almost twice as high as in the other treatments.

We have argued that the observed growth enhancement of Gonyostomum in response to FA was likely due to osmotrophic assimilation of DOC. However, another possibility is that Gonyostomum is capable of bacterial ingestion (phagotrophy). Although attempts were made to feed Gonyostomum with fluorescently labeled bacteria, we could neither demonstrate nor rule out their inclusion into food vacuoles (due to methodological problems caused by trichocyst expulsion). In many flagellates, bacterial ingestion rates and hence growth rates increase with increasing bacterial densities (Sanders et al. 1990). Thus, bacterial ingestion may potentially explain high Gonyostomum growth rates in the Rhodomonas treatment in Expt 1 since bacterial abundance was high in this treatment. However, the observed differences in Gonyostomum growth rates in Expt 2 cannot be explained by discrepancies in bacterial abundance and production rate. Thus, we conclude that osmotrophy is more likely than bacterial ingestion.

The observed mortality of Rhodomonas by Gonyostomum resulted from cell lysis and not from phagotrophy, as we proposed originally. We observed no cells feeding and no food vacuoles in either stained or 
live samples. In the Rhodomonas disappearance experiment (Expt 3), 20 Rhodomonas cells disappeared for each Gonyostomum cell present during the the experiment. Among the hundreds of cells counted, food vacuoles or feeding events would have been detected had they occurred. Hence, we rule out phagotrophy and argue that disappearance of Rhodomonas and increased growth rate of Gonyostomum in its presence were due to cell lysis of Rhodomonas.

Expt 3 indicated that the negative effect of Gonyostomum on Rhodomonas took place primarily when cell-cell contact occurred, whereas positive growth occurred in the cell-free filtrate treatment. Furthermore, in the Induced treatment of the lysis experiment (Expt 4), deformed swollen Rhodomonas cells that were most likely a first stage of lysis were present. These cells also occurred in Expts 1 and 3, but were not quantified since counts were made by flow cytometry. No such lysis effect was seen in the control or in the treatment with Gonyostomum that had been raised in unialgal culture. A small percentage of pre-lysed cells was found in the filtrate treatment on the final sampling occasion. However, the number of lysing cells was low and they were observed only once; we consider this insufficient evidence to suggest that an allelochemical is produced. Instead, our data indicate that Gonyostomum lyses Rhodomonas by cell contact, most likely through the trichocyst firing, either mechanically or through a toxin connected with the trichocyst expulsion. Furthermore, results from both Expts 1 and 4 show and that the lysis effect on Rhodomonas is induced when the species are grown together. Microscope observations (not quantified) suggest that induced Gonyostomum cells have a higher number of trichocysts than Gonyostomum grown unialgally.

Trichocyst extrusion has been proposed to be a protective mechanism that acts mechanically as a grazer deterrent in a marine raphidophyte (Tillmann \& Reckermann 2002). As trichocyst extrusion is known to occur upon stimulation by physical contact, it may occur upon contact with another alga. Uchida et al. $(1995,1999)$ also observed cell lysis after cell contact. The growth of the dinoflagellates Gyrodinium instriatum and Gymnodinium mikimotoi is strongly suppressed when they are cultured together with the dinoflagellate Heterocapsa sp. (a result of cell immobilization and subsequent lysis). Uchida et al. (1999) proposed that inhibition of a competitor after cell contact would be energetically more efficient than inhibition through allelopathy, as the latter is dependent on a constant secretion of a secondary metabolite into the ambient water.

The production of a secondary metabolite such as a toxin has not been documented in Gonyostomum.
However, several closely related marine raphidophytes such as Chattonella spp., Heterosigma akashiwo and Fibrocapsa japonica (Figueroa \& Rengefors 2006) have been responsible for mass mortalities of fish in many areas of the world (Clough \& Strom 2005, Handy et al. 2005). The toxins produced by the marine raphidophytes appear to be neurotoxins similar to the potent brevetoxin (Tillmann \& Reckermann 2002). In addition, marine raphidophytes produce toxic reactive oxygen species such as superoxide, hydrogen peroxide and hydroxyl radicals (Kuroda et al. 2005). Raphidophyte toxins are known to affect herbivorous predators negatively (Clough \& Strom 2005), and the toxin produced by Heterosigma akashiwo significantly inhibits the diatom Skeletonema costatum (Pratt 1966). Recently, it was shown that $H$. akashiwo filtrate had an inhibitory effect on several other marine phytoplankton species (Yamasaki et al. 2007). For Gonyostomum, however, we have no strong evidence of an allelochemical effect, but rather of a cell-contact mediated effect.

In Expt 4, in contrast to Expt 3, we found no decrease in total Rhodomonas cell number. This finding may have 2 causes. First, Gonyostomum was pre-grown with Rhodomonas for only $9 \mathrm{~d}$, in contrast to $40 \mathrm{~d}$ in the disappearance experiment. Presumably, it takes time to induce and build trichocysts. Secondly, a different, perhaps less potent strain was used for the lysis experiment. Surprisingly, we also found a slight stimulatory effect on the total number of Rhodomonas intact cells in the Gonyostomum single treatment in the lysis experiment. Intact cell numbers were significantly higher than the other treatments after $48 \mathrm{~h}$. Apparently, Gonyostomum has some stimulatory effect before its trichocysts are induced.

To summarize, growth of Gonyostomum was stimulated when cells were cultured with another alga and when cells were raised in media enriched with FA. In both cases, growth stimulation may have been the result of either osmotrophically obtained carbon, or by acquisition of a growth factor originating from the FA or released upon cell lysis of Rhodomonas. When cultured together with Gonyostomum, Rhodomonas was severely inhibited, but not grazed upon. We suggest that the mechanism of inhibition is cell lysis, either by mechanical damage due to trichocyst expulsion, or trichocysts combined with a toxin. Moreover, we showed that this cell-contact mediated inhibition was induced by pre-growing Gonyostomum with its competitor. We propose that lysis of competitors may be a strategy by which Gonyostomum remains dominant in the phytoplankton community. We also argue that utlilization of humic substances may contribute to the ability of Gonyostomum to become dominant and maintain blooms. 
Acknowledgements. This project was funded by the Swedish Research Council (VR) to L.-A.H. and the EC 6th framework project SEED (GOCE-CT-2005-003875) to K.R.

\section{LITERATURE CITED}

Bydén S, Larsson AM, Olsson M (1996) Mäta vatten - undersökningar av sött och salt vatten. Inst För tillämpad miljövetenskap, Gothenburg University, Gothenburg

Clough J, Strom S (2005) Effects of Heterosigma akashiwo (Raphidophyceae) on protist grazers: laboratory experiments with ciliates and heterotrophic dinoflagellates. Aquat Microb Ecol 39:121-134

Cronberg G (2005) The life cycle of Gonyostomum semen (Raphidophyceae). Phycologia 44:285-293

Cronberg G, Lindmark G, Björk S (1988) Mass developments of the flagellate Gonyostomum semen (Raphidophyta) in Swedish forest lakes - an effect of acidification? Hydrobiologia 161:217-236

del Giorgio P, Bird DF, Prairie YT, Planas D (1996) Flow cytometric determination of bacterial abundance in lake plankton with green nucleic acid stain SYTO-13. Limnol Oceanogr 41:783-789

Eloranta P, Räike A (1995) Light as a factor affecting the vertical distribution of Gonyostomum semen (Ehr.) Diesing (Raphidophyceae) in lakes. Aqua Fenn 25:15-22

Figueroa RI, Rengefors K (2006) The life cycle and sexuality of the freshwater raphidophyte Gonyostomum semen. J Phycol 42:859-871

Findlay DL, Paterson MJ, Hendzel LL, Kling HJ (2005) Factors influencing Gonyostomum semen blooms in a small boreal reservoir lake. Hydrobiologia 533:243-252

Guillard RRL, Lorenzen CJ (1972) Yellow-green algae with chlorophyllide c. J Phycol 8:10-14

- Handy SM, Coyne KJ, Portune KJ, Demir E and others (2005) Evaluating vertical migration behavior of harmful raphidophytes in the Delaware Inland Bays utilizing quantitative real-time PCR. Aquat Microb Ecol 40:121-132

Hansson LA (1996) Behavioural response in plants: adjustment in algal recruitment induced by herbivores. Proc $\mathrm{R}$ Soc Lond B Biol Sci 263:1241-1244

Hansson LA (2000) Synergistic effects of food chain dynamics and induced behavioral responses in aquatic ecosystems. Ecology 81:842-851

Havens KE III (1989) Seasonal succession in the plankton of a naturally acidic, highly humic lake in Northeastern Ohio, USA. J Plankton Res 11:1321-1327

Hehmann A, Krienitz L, Koschel R (2001) Long-term phytoplankton changes in an artificially divided, top-down manipulated humic lake. Hydrobiologia 448:83-96

Hongve D, Lovstad O, Bjorndalen K (1988) Gonyostomum semen-a new nuisance to bathers in Norwegian lakes. Verh Int Verein Limnol 23:430-434

Jespersen AM, Christoffersen K (1987) Measurements of chlorophyll a from phytoplankton using ethanol as extraction solvent. Arch Hydrobiol 109:445-454

Jones RI (2000) Mixotrophy in planktonic protests: an overview. Freshw Biol 45:219-226

Kritzberg ES, Langenheder S, Lindström ES (2006) Influence of dissolved organic matter source on lake bacterioplankton structure and function-implications for seasonal dynamics of community composition. FEMS Microbiol Ecol 56:406-417

Kuroda A, Nakashima T, Yamaguchi K, Oda T (2005) Isolation and characterization of light-dependent hemolytic cytotoxin from harmful red tide phytoplankton Chattonella

Editorial responsibility: Robert Sanders,

Philadelphia, Pennsylvania, USA marina. Comp Biochem Physiol 141(Part C):297-305

Le Cohu PR, Guitard N, Comoy N, Brabet J (1989) Gonyostomum semen, a potential nuisance in large French reservoirs? The case of the Pareloup lake. Arch Hydrobiol 117:225-236

Legrand C, Carlsson P (1998) Uptake of high molecular weight dextran by the dinoflagellate Alexandrium catenella. Aquat Microb Ecol 16:81-86

Lepistö L, Saura M (1998) Effects of forest fertilization on phytoplankton in a boreal brown-water lake. Boreal Environ Res 3:33-43

Lepistö L, Antikainen S, Kivinen J (1994) The occurrence of Gonyostomum semen (Ehr.) Diesing in Finnish lakes. Hydrobiologia 273:1-8

Pithart D, Pechar L, Mattsson G (1997) Summer blooms of raphidophyte Gonyostomum semen and its diurnal vertical migration in a floodplain pool. Algol Stud 85:119-133

Pratt DM (1966) Competition between Skeletonema costatum and Olisthodiscus luteus in Narragansett Bay and in culture. Limnol Oceanogr 11:447-455

Salonen K, Rosenberg M (2000) Advantages from diel vertical migration can explain the dominance of Gonyostomum semen (Raphidophyceae) in a small, steeply-stratified humic lake. J Plankton Res 22:1841-1853

Salonen K, Holopainen AL, Keskitalo J (2002) Regular high contribution of Gonyostomum semen to phytoplankton biomass in a small humic lake. Verh Int Verein Limnol 28:488-491

Sanders RW, Porter KG, Caron DA (1990) Relationship between phototrophy and phagotrophy in the mixotrophic chrysophyte Poterioochromonas malhamensis. Microb Ecol 19:97-109

Sanders RW, Caron DA, Davidson JM, Dennett MR, Moran DM (2001) Nutrient acquisition and population growth of a mixotrophic alga in axenic and bacterized cultures. Microb Ecol 42:513-523

Sherr EB, Sherr BF (1993) Protistan grazing rates via uptake of fluorescently labeled prey. In: Kemp PF, Sherr BF, Sherr EB, Cole JJ (eds) Handbook of methods in aquatic microbial ecology. Lewis Publishers, Boca Raton, FL, p 695-701

Skovgaard A (1996) Mixotrophy in Fragilidium subglobosum (Dinophyceae): growth and grazing responses as functions of light intensity. Mar Ecol Prog Ser 143:247-253

Smith DC, Azam F (1992) A simple economical method for measuring bacterial protein synthesis in sea water using ${ }^{3}$ H-leucine. Mar Microb Food Webs 6:107-109

Tillmann U, Reckermann M (2002) Dinoflagellate grazing on the raphidophyte Fibrocapsa japonica. Aquat Microb Ecol 26:247-257

Tittel J, Kamjunke N (2004) Metabolism of dissolved organic carbon by planktonic bacteria and mixotrophic algae in lake neutralization experiments. Freshw Biol 49: 1062-1071

Uchida T, Yamaguchi M, Matsuyama Y, Honjo T (1995) The red-tide dinoflagellate Heterocapsa sp. kills Gyrodinium instriatum by cell contact. Mar Ecol Prog Ser 118:301-303

Uchida T, Toda S, Matsuyama Y, Yamaguchi M, Kotani Y, Honjo $\mathrm{T}$ (1999) Interactions between the red tide dinoflagellate Heterocapsa circularisquama and Gymnodinium mikimotoi in laboratory culture. J Exp Mar Biol Ecol 241:285-299

Wetzel RG, Likens GE (1991) Limnological analyses, 2nd edn. Springer, Berlin

> Willén E (2003) Dominance patterns of planktonic algae in Swedish forest lakes. Hydrobiologia 502:315-324

Yamasaki Y, Nagasoe S, Matsubara T, Shikata T, Shimasaki Y, Oshima Y, Honjo T (2007) Allelopathic interactions between the bacillariophyte Skeletonema costatum and the raphidophyte Heterosigma akashiwo. Mar Ecol Prog Ser 339:83-92

Submitted: December 5, 2006; Accepted: December 30, 2007 Proofs received from author(s): February 15, 2008 